\title{
New host record of pea crab Arcotheres purpureus (Alcock, 1900) (Crustacea: Decapoda: Pinnotheridae) with first description of male
}

\author{
Biswaprajna Mohanty ${ }^{1}$, Dipti Raut ${ }^{*}$, Malay Kanti Dev Roy², Akkur V. Raman³, Lipika Patnaik ${ }^{1}$, Aswini Nayak, \\ Sonali Sanghamitra Rout ${ }^{1}$ and Bhagyashree Dash ${ }^{1}$
}

\begin{abstract}
Background: Arcotheres purpureus, a species of pea crab has been reported from the Red Sea, Maldives and Andaman Sea with no description of the male. According to existing literature the single host for this species is Ostrea.

Methods: The specimens examined were obtained from the dredge hauls.

Results: In the present study we report Arcotheres purpureus for the first time from the coastal waters of mainland India. The specimens have been observed within the mantle cavity of a venerid bivalve Protapes gallus a new host record for this species. A description of the male specimen is also communicated herein for the first time.

Conclusions: Bivalve fisheries is an alternative livelihood option for the fishermen of this region. In this context the manifestation of Arcotheres purpureus, from a commercially viable species of bivalve such as Protapes gallus as well as its incidence in waters of mainland, India is a cause for concern necessitating further investigations.
\end{abstract}

Keywords: Arcotheres purpureus, First male record, Subsistence fisheries, Devi estuary, Odisha, India

\section{Background}

Members of family Pinnotheridae of the brachyuran infraorder are nearly all symbionts of invertebrates, some are parasitic and others are commensals. Most of these species live inside bivalve molluscs or in the tubes or burrows of polychaetes and other marine organisms (McDermott, 2009). As globally ubiquitous symbionts of the marine environment, these pea crabs cause serious economic impact in the aquaculture production of several major bivalve species (Trottier and Jeffs, 2015).

Female specimens of Arcotheres purpureus (Alcock, 1900) from a bivalve Ostrea sp. (family Ostreidae) were first reported and described from waters of the Andaman sea. Later on, the species was reported from Maldives (Borradaile, 1903) and the Red sea as

\footnotetext{
* Correspondence: raut.dipti2@gmail.com

${ }^{1}$ Environmental Science Laboratory, Department of Zoology, Ravenshaw University, Cuttack, Odisha 753003, India

Full list of author information is available at the end of the article
}

Pinnotheres purporeus (Vine, 1986). A compilation of Pinnotheroidea species with their hosts and sex (Theil et al., 2016) updated ( $\mathrm{Ng}$ et al., 2008) indicates the occurrence of only the female specimen of Arcotheres purpureus from species of Ostrea in the Red sea, Gulf of Aden, Andaman and Maldive Islands (Schmitt et al, 1973). Thereafter, there have been no reports of the mentioned species.

The occurrence of both the sexes particularly males for the first time, from the coastal waters of mainland peninsular India (19 58'27.62"N, 086 20'20.38" E), Astarang, Odisha in the present study, is of interest as well as concern for a region known for subsistence fisheries as a source of livelihood. The objective of this communication is to place on record a species of pea crab Arcotheres purpureus hitherto not reported earlier from a new host bivalve Protapes gallus (Gmelin, 1791), of the family Veneridae used extensively by fishers for their livelihood. A description of the male not specified by 


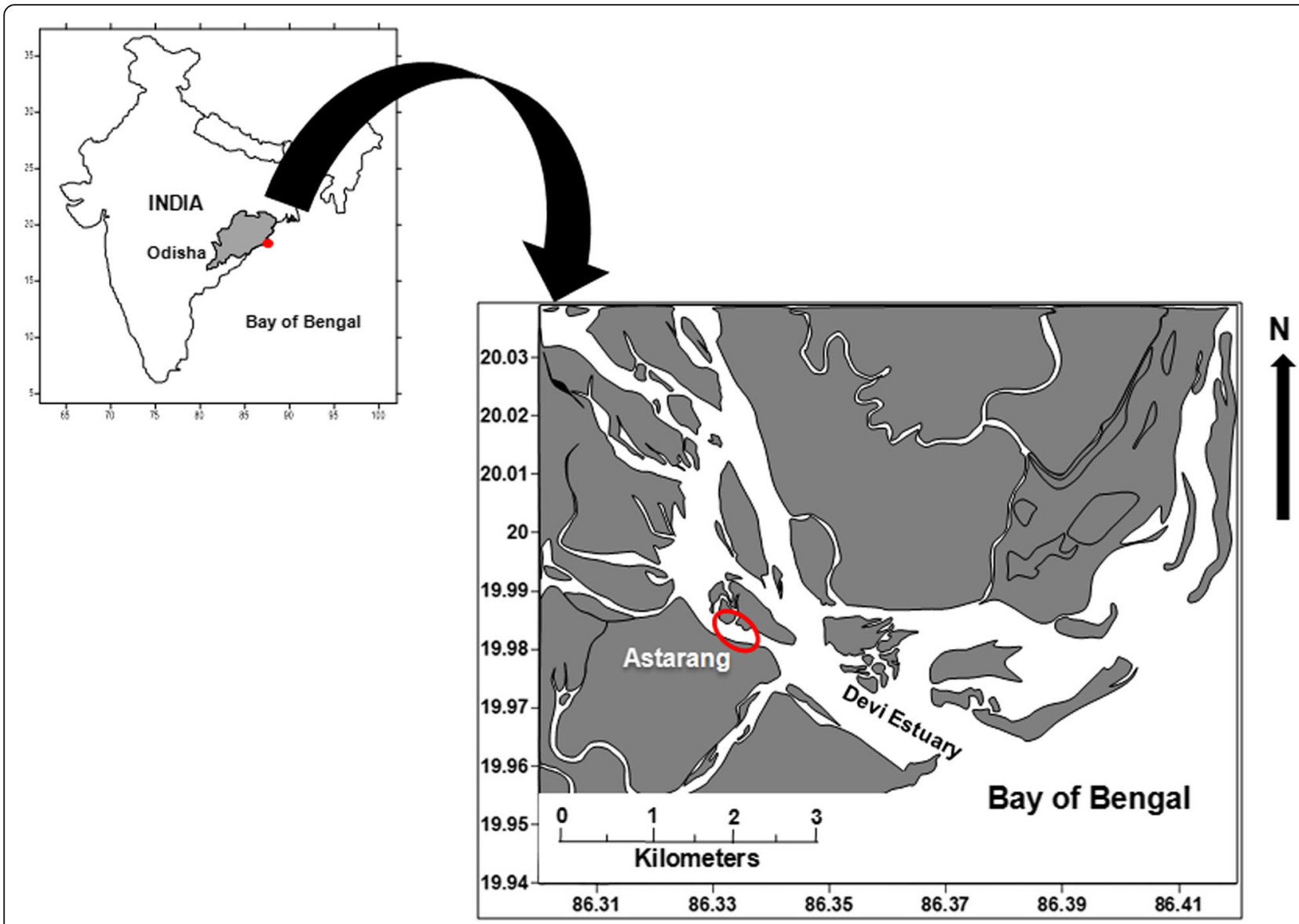

Fig. 1 Location maps showing the Devi estuary and environs Astarang, east coast of India

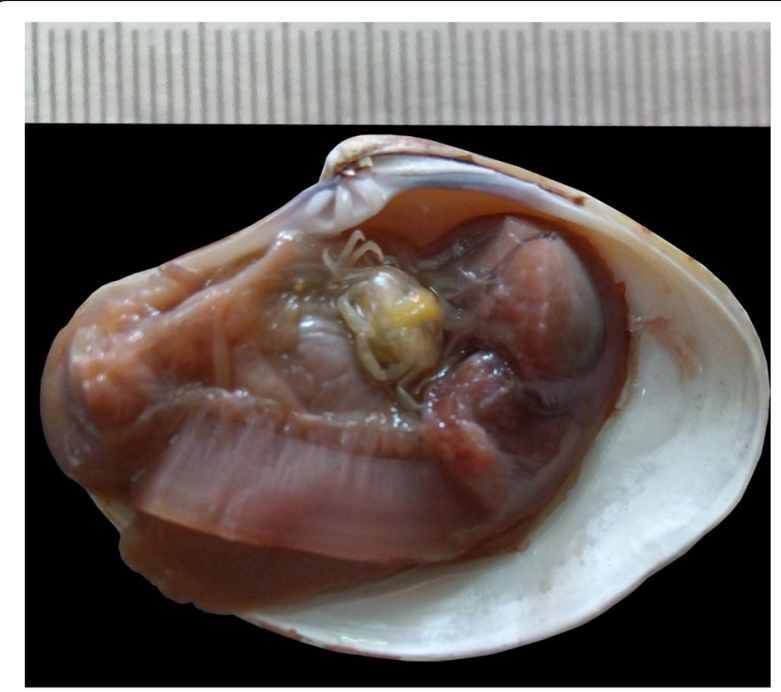

Fig. 2 Arcotheres purpureus (Alcock, 1900) Female within the host Protapes gallus (Gmelin, 1791)
Alcock, 1900 in the original description of the species and subsequent authors is provided herein for the first time.

\section{Methods}

The specimens examined were obtained from the dredge hauls (June, 2015), at Nuagarh fishing harbour of Astarang, Devi estuary $\left(19^{\circ} 58^{\prime} 45.16^{\prime \prime} \mathrm{N}-86^{\circ} 20^{\prime} 32.54^{\prime \prime} \mathrm{E}\right)$ the largest tributary of River Mahanadi on the east coast of

Table 1 Morphometric measurements of male and female Arcotheres purpureus (Alcock, 1900)

\begin{tabular}{lll}
\hline & Male & Female \\
\hline Carapace width & $5.2 \mathrm{~mm}$ & $7.0 \mathrm{~mm}$ \\
Carapace length & $4.3 \mathrm{~mm}$ & $6.0 \mathrm{~mm}$ \\
Dactylus of cheliped & $1.4 \mathrm{~mm}$ & $1.5 \mathrm{~mm}$ \\
Propodus of cheliped & $3.0 \mathrm{~mm}$ & $3.2 \mathrm{~mm}$ \\
Carpus of cheliped & $1.5 \mathrm{~mm}$ & $1.6 \mathrm{~mm}$ \\
Merus of cheliped & $1.2 \mathrm{~mm}$ & $1.3 \mathrm{~mm}$ \\
Dactylus of 3rd leg & $1.0 \mathrm{~mm}$ & $1.1 \mathrm{~mm}$ \\
Dactylus of 4th leg & $0.9 \mathrm{~mm}$ & $1.0 \mathrm{~mm}$ \\
\hline
\end{tabular}


a
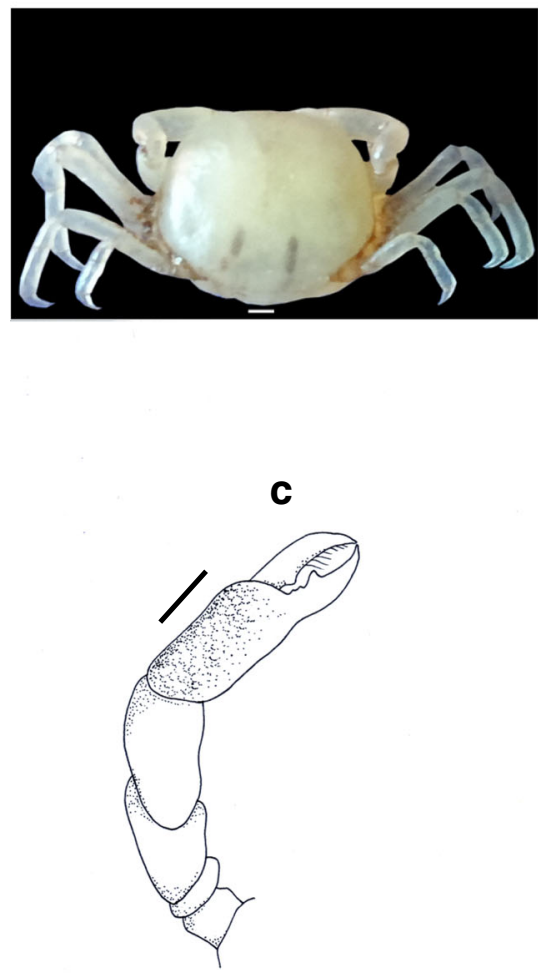

e

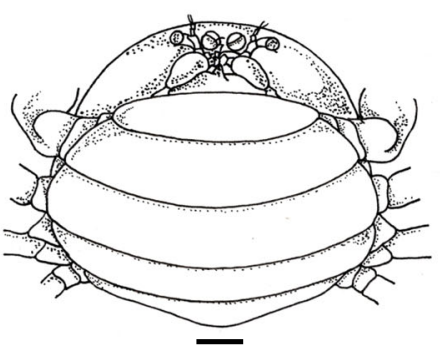

b
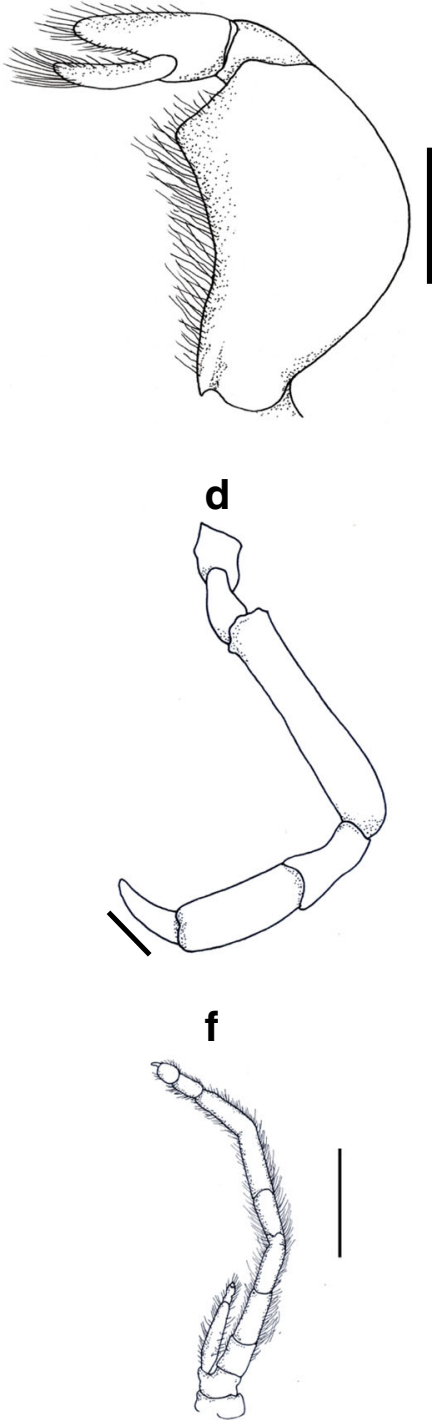

Fig. 3 Arcotheres purpureus (Alcock, 1900) Female: a Dorsal view; b Left third maxilliped; c Left chela; d Right 3rd pereiopod; e Ventral view; $\mathbf{f}$ left pleopod. Scales $\mathbf{a}, \mathbf{c}, \mathbf{d}, \mathbf{e}, \mathbf{f}=1.0 \mathrm{~mm} ; \mathbf{b}=0.5 \mathrm{~mm}$

India, Odisha (Fig. 1). Permission for carrying out faunistic studies in the study area was obtained from the office of the Principal CCF (Wildlife) and Chief Wildlife Warden, Odisha. A male specimen was obtained in the free-living condition while the female was found within the mantle cavity of venerid bivalve Protapes gallus. In the laboratory, the specimens were carefully removed from the mantle cavities, identified using appropriate taxonomic literature (Alcock, 1900) measured to the nearest $0.1 \mathrm{~mm}$ using Vernier callipers, preserved in 10\% neutralised formaldehyde and deposited in the Environmental Science Laboratory Museum, Department of Zoology, Ravenshaw University, Cuttack, Odisha,
India (Reg. No. RZEV Ravenshaw Zoology Environmental Crab Brachyura CB-36 and CB-37). Terminology used follows Manning (1993). Abbreviations used are MXP3 = Maxilliped 3; P2-P5 = Pereiopod 25; G1 = Gonopod 1.

\section{Results}

Systematic account

Family Pinnotheridae De Haan 1833.

Genus Arcotheres Manning, 1993

Species purpureus Alcock, 1900

Type species: Pinnotheres purpureus Alcock, 1900, type locality: Andaman sea. 
a

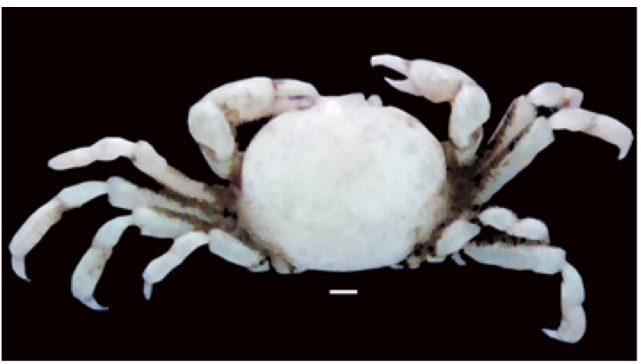

C

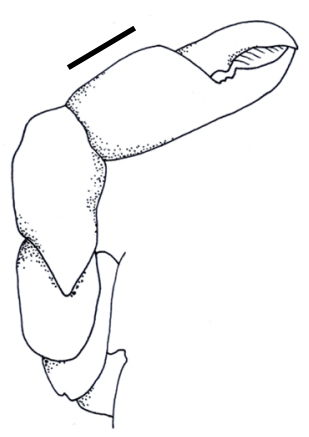

e

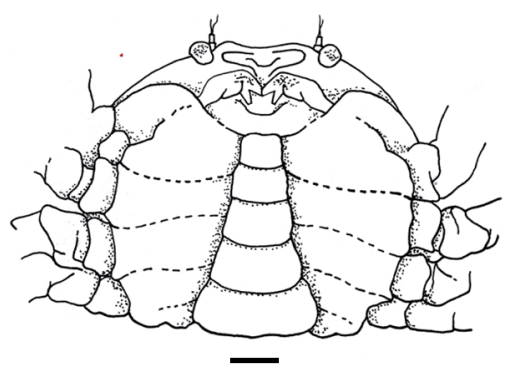

b

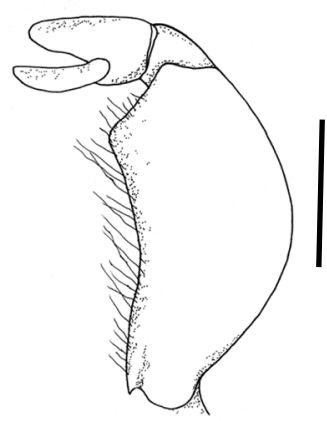

d

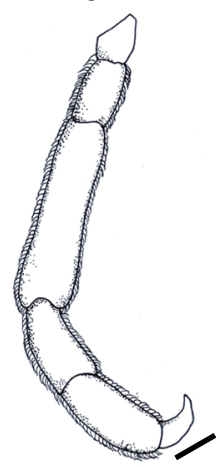

f

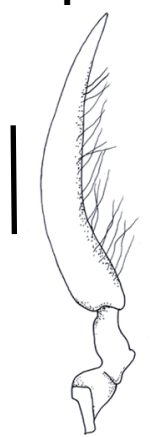

Fig. 4 Arcotheres purpureus (Alcock, 1900) male: a Dorsal view; b Left third maxilliped; c Left chela; $\mathbf{d}$ Left 3rd pereiopod; e Ventral view; $\mathbf{f}$ Left gonopod1. Scales $\mathbf{a}, \mathbf{c}, \mathbf{d}, \mathbf{e}, \mathbf{f}=1.0 \mathrm{~mm} ; \mathbf{b}=0.5 \mathrm{~mm}$

\section{Arcotheres purpureus (Alcock, 1900) (Fig. 2, Table 1)}

Material examined $1 \hat{\delta}$ and $1 \uparrow$ specimen (Devi estuary, Odisha, 20. 02. 2015, (BM), Reg. No. RZEV CB-36 and CB-37 with morphometric measurements (Table 1).

\section{Description and diagnosis}

\section{Female (Fig. 3 a-f)}

Carapace subhexagonal, in outline, smooth and glabrous with convexed dorsal surface, slightly wider than longer, width $\backslash$ length ratio in the order 1.16. Eyes and front not visible dorsally (Fig. 3a). Third maxilliped (MXP3) hairy with fine elongated pubescence on inner margin, dactylus joined with propodus along ventral margin (Fig. 3b). Palm of cheliped slightly more than the length of dactylus, inner margin of movable finger with sparsely distributed setae. Two teeth seen in the inner proximal margins - one on each of the movable finger and pollex of cheliped (Fig. 3c). Walking legs generally slender, weak, polished with pointed dactylus (Fig. 3d); merus and dactylus of pereiopods in the order of length P3 > P4 > P2 > P5 observed, third pair of legs longest. Abdomen of seven separate segments, almost covering two-third of ventral surface, segments 1 and 2 not visible ventrally (Fig. 3e). Pleopod 1 of female contains delicate hairs on both margins (Fig. 3f). 


\section{Male (Fig. $4 a-f$ )}

Carapace subhexagonal, anterolateral margin slightly acute, well calcified, surface smooth slightly wider than long, width \length ratio in the order 1.20 (Fig. 4a). Eyes and front prominent, the latter slightly notched medially, visible dorsally. Very few hairs towards inner margins of MXP3 (Fig. 4b). Chelipeds and legs stouter compared to females (Fig. 4c-d). Inner margin of movable finger of cheliped beset with sparsely distributed setae as in females. Inner proximal margin of movable finger and pollex of cheliped with one tooth each (Fig. 4c). Excluding dactylus, both margins of walking legs fringed with dense hairs (Fig. 4d). Dactylus and merus of pereiopods in the order of length P3 $>$ P4 $>$ P2 $>$ P5. Abdomen triangular, sevenjointed, somite 3 of the abdomen largest, first and second somites not visible ventrally, penultimate segment wider than long, telson squarish at the tip (Fig. 4e). Outer margin of G1 in male finely hirsute (Fig. 4f).

\section{Colour}

Male deep purple while female pale red in fresh conditions. Ovigerous female in the host appeared cream orange. Female specimen hyaline in contrast to opaque male.

\section{Habitat}

Found in loamy fine sand (sand $85.12 \%$, silt $14.83 \%$, clay $0.06 \%$, organic matter $0.52 \%$ ), salinity 29 psu. Depth 25-30 m.

\section{Distribution}

Andaman Sea, Maldives and Red Sea.

Presently observed for the first time from mainland India.

\section{Discussion}

The family Pinnotheridae includes 57 genera and 461 species worldwide (Davie and Türkay, 2009). A review of Pinnotheridae from India records 23 species (Dev Roy, 2014) and an additional new species Afropinnotheres ratnakara (Ng and Kumar, 2015). In a reappraisal of the taxonomy of species under this family, based on the structure of MXPs, asymmetrical length of third walking legs and P2-P5, Ng and Kumar (op. cit) moved Pinnotheres purpureus Alcock, 1900 to the genus Arcotheres Manning, 1993. The specimens under consideration in this study reveal similar features (MXP3 with ischium and merus imprecisely fused, propodus exceeding carpus in length. Dactylus of MXP3 hinged with propodus along ventral margin, sub hexagonal shape of the carapace) hence assigned to the genus Arcotheres.

The presence of Arcotheres purpureus within the mantle cavity of bivalve Protapes gallus could be a case of kleptoparasitism. Protapes gallus serving as a host for Arcotheres purpureus is a suspension feeder. Pea crabs are known to filter fine organic particles from the water and feed on the mucus produced by host gills as well as food particles accumulated in mucus (Kruczynski, 1975). Whether, feeding by Arcotheres purpureus adversely impacts bivalve host gills, and other physiological aspects needs to be examined as such effects could affect the bivalve fisheries of the region. In the immediate environs of Devi estuary, Astarang, Odisha, bivalve species particularly Protapes gallus have been used as meat for consumption, poultry feed, in hatcheries, as fertilizers and largely for the extraction of lime, popularly incorporated into the formulation of betel (Piper betle) quid chewed by the local population for its assumed stimulant and psychoactive effects (Gupta and Ray 2004). It is also utilised in the preparation of various tobacco based products as reported from other coastal regions of Odisha (Panda and Misra, 2007).

\section{Conclusion}

Molluscan fisheries as the kind practised in Astarang (handpicking from the intertidal mud flats, indigenous fishing methods using small country boats) has been a sustainable alternative livelihood option particularly during the fishing ban periods observed in coastal India. Worldwide, informal small-scale fisheries and other fisheries related activities are recognised as significant contributors to nutrition, food security, sustainable livelihood and poverty alleviation of developing countries (Staples et al., 2004). In this context, the occurrence of pea crab, Arcotheres purpureus as a kleptoparasite in a bivalve species used as a source of sustainable livelihood for the coastal population is a matter of concern. Further studies on host pea crab infestation needs to be carried out and suitable measures taken to control such outbreaks if found deleterious, as pinnotherids could have a negative commercial implication on aquaculture and fisheries of bivalves (Narvarte and Saiz, 2004) as well as the livelihood of fishers.

The present finding assumes significance with the incidence of Arcotheres purpureus for the first time from a new host bivalve Protapes gallus of the family Veneridae. A description of the male specimen is provided for the first time.

\footnotetext{
Abbreviations

BM: Biswaprajna Mohanty; G1: Gonopod 1; MXP3: Maxilliped 3; P2P5: Pereiopod 2-5; Reg. No.: Registration number; RZEV CB-36: Ravenshaw Zoology Environmental Crab Brachyura 36; RZEV CB-37: Ravenshaw Zoology Environmental Crab Brachyura 37
}

\section{Acknowledgements}

We thank Mr. Jeet Mohanty, Artist for the figures and Dr. B. Charan Kumar, DST Young Scientist, Andhra University for the maps. Thanks to the Principal CCF (Wildlife) and Chief Wildlife Warden, Government of Odisha, India for necessary permission. Laboratory facilities and logistic support provided by the Department of Zoology, Ravenshaw University, Cuttack, Odisha are appreciated. Due thanks to the reviewers for their valuable comments. 


\section{Funding}

The authors gratefully acknowledge the financial support in the form of a project grant (260/OBB, dated 06th September, 2014) by Odisha Biodiversity Board, Bhubaneshwar.

\section{Availability of data and materials}

All data generated during this study are included in this article and the specimens are deposited in the Ravenshaw Zoology Environmental Science Laboratory museum with their Registration numbers.

\section{Authors' contributions}

$B M, A N, S S R$ and BD carried out the field study. MKD identified the specimen. DR, BM, MKD, AVR and LP drafted the manuscript. LP and BM photographed the specimens. All authors read and approved the final manuscript.

\section{Ethics approval and consent to participate}

Not applicable

\section{Consent for publication}

Not applicable

\section{Competing interests}

The authors declare that they have no competing interests.

\section{Publisher's Note}

Springer Nature remains neutral with regard to jurisdictional claims in published maps and institutional affiliations.

\section{Author details}

${ }^{1}$ Environmental Science Laboratory, Department of Zoology, Ravenshaw University, Cuttack, Odisha 753003, India. ${ }^{2}$ Formerly in Crustacea Section, Zoological Survey of India, 27 Jawaharlal Nehru Road, Kolkata 700016, India. ${ }^{3}$ Marine Biology Laboratory, Andhra University, Visakhapatnam, AP 530003, India.

Received: 5 January 2017 Accepted: 18 January 2018

Published online: 27 January 2018

\section{References}

Alcock A. Material for a Carcinological Fauna of India. No. 6: the Brachyura Catometopa, or Grapsoidea. J Asiat Soc Bengal. 1900;69:279-456. https://doi. org/10.5962/bhl.title.15344

Borradaile LA. Marine crustaceans. Part V. The crabs of the Catametope. In: Gardiner JS, editor. Fauna and Geography of the Maldive and Laccadive archipelagoes, vol. I. Cambridge: University Press; 1903. p. 431-2.

Davie P, Türkay M. WoRMS - World Register of Marine Species. Marinespecies.org. 2009. Available at: http://www.marinespecies.org. Accessed 18 Nov 2017.

Dev Roy MK. An inventory of decapod crustaceans from India. J Environ Sociobiol. 2014;11:219-74.

Gupta PC, Ray CS. Epidemiology of betel quid usage. Ann Acad Med Singap. 2004;33 suppl:31-6.

Kruczynski WL. A radioactive tracer study of food uptake by Pinnotheres maculatus in Molluscan hosts. Biol Bull. 1975;148:60-7.

Manning RB. West African pinnotherid crabs, subfamily Pinnotherinae (Crustacea, Decapoda, Brachyura). Bull Mus Natl Hist Nat. 1993;15(1):125-78.

McDermott JJ. Hypersymbioses in the pinnotherid crabs (Decapoda: Brachyura: Pinnotheridae): a review. J Nat Hist. 2009;43(13-14):785-805. https://doi.org/ $10.1080 / 00222930802702480$

Narvarte MA, Saiz MN. Effects of the pinnoterid crab Tumidotheres maculatus on the Tehuelche scallop Aequipecten tehuelchus in the San Matías Gulf, Argentina. Fish Res. 2004;67:207-14.

Ng PKL, Guinot D, Davie PJF. Systema Brachyura: part I. An annotated checklist of extant brachyuran crabs of the world. Raffles Bull Zool. 2008;Suppl. 17:1-286.

$\mathrm{Ng}$ PKL, Kumar AB. A new species of Afropinnotheres Manning, 1993 (Crustacea, Brachyura, Pinnotheridae) from south western India, the first record of the genus from the Indian Ocean, with a review of the Pinnotheridae of India and adjacent seas. Zootaxa. 2015;3947(2):264-74. https://doi.org/10.11646/ zootaxa.3947.2.8

Panda A, Misra MK. Traditional lime preparation-a case study in coastal Orissa, India. Indian J Tradit Knowl. 2007;6:262-9.
Schmitt WL, McCain JC, Davidson ES. Fam. Pinnotheridae. Brachyura I: Decapoda I. In: Gruner HE, Holthuis LB, editors. Crustaceorum Catalogus. W. Junk, Den Haag, vol. 3; 1973. p. 1-160. https://doi.org/10.3366/jsbnh.1974.7.1.144.

Staples D, Satia B, Gardiner PR. A research agenda for small-scale fisheries, FAO/ RAP publication/FIPL/C10009. Rome: FAO; 2004.

Theil EM, Cuesta JA, Felder LD. Molecular evidence for non-monophyly of the pinnotheroid crabs (Crustacea: Brachyura: Pinnotheroidea), warranting taxonomic reappraisal. Invertebrate Systematics Suppl. 2016;30:1-27.

Trottier O, Jeffs AG. Mate locating and access behaviour of the parasitic pea crab, Nepinnotheres novaezelandiae, an important parasite of the mussel Perna canaliculus. Parasite. 2015;22:13. http://doi.org/10.1051/parasite/2015013

Vine P. Red Sea invertebrates. London: IMMEL Publishing; 1986.

\section{Submit your next manuscript to BioMed Central and we will help you at every step:}

- We accept pre-submission inquiries

- Our selector tool helps you to find the most relevant journal

- We provide round the clock customer support

- Convenient online submission

- Thorough peer review

- Inclusion in PubMed and all major indexing services

- Maximum visibility for your research

Submit your manuscript at www.biomedcentral.com/submit
C Biomed Central 